\title{
LONG-TERM INVESTIGATION OF METAL CONCENTRATIONS IN BROWN ALGAE Fucus vesiculosus FROM THE GULF OF RIGA, BALTIC SEA
}

\author{
Zinta Seisuma, Irina Kuḷikova, Uldis Botva and Elmīra Boikova \\ Institute of Biology, University of Latvia, Miera iela 3, Salaspils, LV-2169, LATVIA \\ E-mail: zinta@inbox.Iv
}

Communicated by Māris Kḷaviṇš

\begin{abstract}
The study was conducted in the coastal area of the Gulf of Riga at three stations (Ainaži, Saulkrasti, Mērsrags) from 1997 till 2010. Brown algae samples were collected at 3.0-m depth from a boat using scuba gear in August and September. The concentrations of metals ( $\mathrm{Cd}, \mathrm{Pb}, \mathrm{Cu}, \mathrm{Ni}$, $\mathrm{Zn}$ ) were determined by atomic absorption spectrophotometry method (model Spektra A 880), and of Hg by FIMS (Flow Injection Mercury System, Perkin Elmer). The aim of this investigation was to determine the concentration levels of metals ( $\mathrm{Hg}, \mathrm{Cd}, \mathrm{Pb}, \mathrm{Cu}, \mathrm{Ni}, \mathrm{Zn})$ in the dominant species of macroalgae (Fucus vesiculosus) in the Gulf of Riga in different stations and years. Metal concentrations in $\mathrm{F}$. vesiculosus varied between sampling years and stations, and significant differences in $\mathrm{Hg}, \mathrm{Pb}$ and Ni concentrations between years were detected. In some years the concentrations of metals in $\mathrm{F}$. vesiculosus were similar in all three stations. Brown algae $\mathrm{F}$. vesiculosus can accumulate metals to concentrations thousand times higher than in marine water.
\end{abstract}

Key words: Fucus vesiculosus, $\mathrm{Hg}, \mathrm{Cd}, \mathrm{Pb}, \mathrm{Cu}, \mathrm{Ni}, \mathrm{Zn}$, Gulf of Riga (Baltic Sea).

\section{INTRODUCTION}

Measurements are usually focused on biota and only secondarily on surface sediments or water, as biota can describe more reliably the state of the environment (Anonymous, 2010).The first measurements of $\mathrm{Hg}, \mathrm{Cd}, \mathrm{Cr}, \mathrm{Cu}, \mathrm{Ni}, \mathrm{Pb}$, $\mathrm{Mn}, \mathrm{Zn}, \mathrm{Sr}, \mathrm{Fe}$ and $\mathrm{Mg}$ concentrations in Fucus vesiculosus were made during the period 1977-1980 (Сейсума и др. 1984) in the coastal area of the Gulf of Riga. The brown algae were sampled at Kolka, Roja, Mērsrags, Engure, Ragaciems, Lielupe, Daugavgrīva, Skulte, Tūja, Vitrupe, Jaagupe, Pērnava, and Varbla. Regular study of $\mathrm{Hg}, \mathrm{Cd}, \mathrm{Pb}$, $\mathrm{Cu}, \mathrm{Ni}, \mathrm{Zn}, \mathrm{Mn}$ and $\mathrm{Fe}$ levels in $F$. vesiculosus was renewed in 1997. Samples of brown algae were collected at three sites (Ainaži, Saulkrasti and Mērsrags) in the Gulf of Riga to have more complete knowledge of metal levels in plants of the Gulf. F. vesiculosus is a common perennial species that is tolerant to high salinity fluctuations. It grows on sandy bottoms with stones of various size and prefers coastal zones without tides. The brown algae $F$. vesiculosus is a dominant macroalgae of the Gulf of Riga and of the whole Baltic Sea. This brown algae is considered to be a good bioindicator (Bryan and Hummerstone, 1973; Phillipps, 1977; Bryan, 1983; Barnett and Ashcroft, 1985; Forsberg et al., 1988; O'Leary and Breen, 1998; Barreiro et al., 2002; Cairrao et al., 2007) similar to the brown algae Ascophyllum nodosum that grows along the Irish coast (Morrison et al., 2008). An indicator organism should fulfill the following requirements, among others: be of a reasonable size, sedentary, easily collected and abundant in the investigated area. Water plants possess some characteristic features that enable them to absorb metals essential for their growth and development from sediments and water. These metals include $\mathrm{Cu}, \mathrm{Zn}$, Ni. Water plants accumulate also toxic metals that may lack any biological function, such as $\mathrm{Hg}, \mathrm{Cd}$ and $\mathrm{Pb}$.

The Estonian scientist G. Martin (1999) divides phytobenthic communities of the Gulf of Riga into three groups with different structure and distribution patterns. Group 1 is dominated by filamentous green and brown algae located in areas receiving eutrophic fresh waters i.e. in the area north from the Daugava river inflow. Our selected station Saulkrasti belongs to this group. Our investigations (Boikova et al., 2003), as described by G. Martin, indicate that the communities are characterised by low species diversity and strong dominance of a single species. Group II is characterised by a considerable number of species and relatively low biomass and coverage: these communities are found along the eastern and south-western coast of the Gulf of Riga. Our station Ainaži belongs to this group. The third group has the highest biomass and coverage values. This group of communities occupies the littoral zone along the western coast of the Gulf of Riga. Our Mērsrags station corresponds to this group. At that station (Boikova et al., 2003) 16 macrophyte species occur in large underwater meadows with ver- 
tical distribution up to $10 \mathrm{~m}$ depth. In comparison, species richness at the east coast station Saulkrasti, which is subject to eutrofication, was only 10 and vertical distribution was twice smaller - 4-5 m.

The aim of our investigation was to determine the concentration levels of metals $(\mathrm{Hg}, \mathrm{Cd}, \mathrm{Pb}, \mathrm{Cu}, \mathrm{Ni}, \mathrm{Zn})$ in the dominant species of macroalgae (Fucus vesiculosus) in the Gulf of Riga in different stations and years.

\section{MATERIALS AND METHODS}

Brown algae $F$. vesiculosus samples were collected at three stations of the Gulf of Riga: Ainaži, Saulkrasti and Mērsrags at 3-m depth in August/September (Fig. 1) from boat by a scuba diver. The samples of plants were washed thoroughly in the field with sea water. On arrival to the laboratory epiphytes present on the plants were manually removed and samples were dried at room temperature. Dry weight was determined after drying in an oven at a constant temperature of $80{ }^{\circ} \mathrm{C}$. Then water plants were weighed and ashed at $500{ }^{\circ} \mathrm{C}$ in a muffle furnace (Сейсума и др., 1984). All of the plant samples were run in triplicate. The concentrations of metals $(\mathrm{Cd}, \mathrm{Pb}, \mathrm{Cu}, \mathrm{Ni}, \mathrm{Zn})$ were determined by atomic absorption spectrophotometry (AAS) method with a Varian AA Spectrometer (model Spectra A880), and $\mathrm{Hg}$ content using a Flow Injection Mercury System (FIMS, Perkin Elmer). Internationally accepted standard reference samples of plants $-\mathrm{BCR}^{\mathrm{R}}-060$ were used for quality control.

At the sampling sites, simultaneously with the collection of brown algae $F$. vesiculosus, water and sediment samples were taken for analysis of metals (Seisuma and Kulikova, 2006), and the following measurements were made: water temperature, $\mathrm{pH}$, salinity ( $\mathrm{S} \%$ ), Secci depth (m), dissolved inorganic nitrogen (DIN, $\mu \mathrm{M})$, and dissolved inorganic phosphorus (DIP, $\mu \mathrm{M})$. Also, samples of $F$. vesiculosus were taken for determination of biomass $\left(\mathrm{g} / \mathrm{m}^{2}\right.$ dry $\left.\mathrm{wt}\right)(\mathrm{Ta}-$ ble 1).

In summer, water temperature fluctuated from 10 to $24{ }^{\circ} \mathrm{C}$. The lowest temperatures were observed in 1997 in the Saulkrasti station and in 2001 in the Mērsrags station, when temperature fell to $10{ }^{\circ} \mathrm{C}$. Water salinity in the coastal stations fluctuated between 4.5 and $5.7 \%$, and relatively lower salinity was found at the Saulkrasti station. A decrease of $\mathrm{pH}$ value to 7.94, was observed when water temperature fell due to coastal upwelling processes.

Increased levels of biogenic elements were observed in 2001 and 2010 collections (DIN reached 3-4 $\mu \mathrm{M}$, DIP surpassed $0.20 \mu \mathrm{M})$.

Water transparency fluctuated from 1.1 to $3.0 \mathrm{~m}$ (Secci depth). The lowest values were found in the Saulkrasti station and highest transparency in the Mērsrags station. A higher water transparency was observed in 2007 and 2009 when biomass of $F$. vesiculosus was also high (except in the Saulkrasti station).

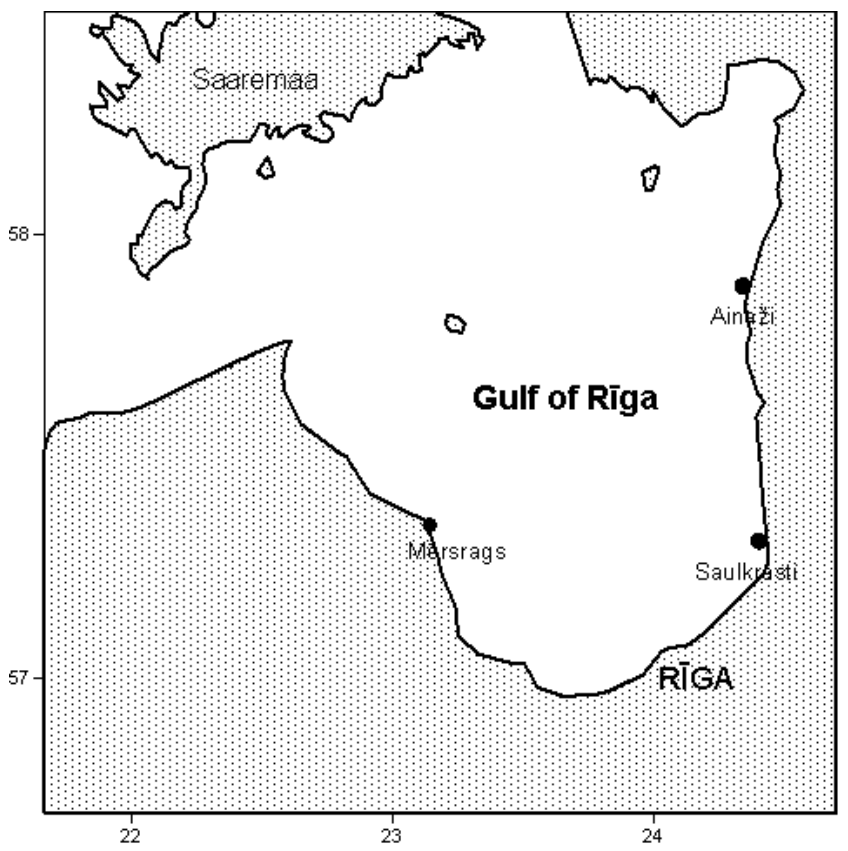

Fig. 1. Location of sampling stations.

Mean metal concentrations and standard deviations were calculated for $F$. vesiculosus.

Two-way analysis of variance (ANOVA) without replication was used to examine effects of station and years on brown algae $F$. vesiculosus metal concentration (Arhipova un Bāliņa, 2003). To identify related variables (metals) and samples (stations), principal component analysis (PCA) using a correlation matrix was performed using the SAS programme package (Anonymous, 1998).

\section{RESULTS}

Differences in the metals levels (Table 2) in the brown algae F. vesiculosus differed between the years 1997/1999 to 2010. The concentration of $\mathrm{Hg}$ in $F$. vesiculosus at Ainaži differed by 2.5 times, at Saulkrasti by 5.9 times and at Mērsrags by 4.6 times (ANOVA test, Table 3). The differences in $\mathrm{Hg}$ levels among the brown algae at Ainaži, Saulkrasti and Mērsrags stations in 2001, 2005, 2007 did not significantly differ, while in 1999, 2003, 2009 and 2010 they differed by 1.9-2.9 times.

The differences in $\mathrm{Cd}$ levels in the brown algae $F$. vesiculosus during 1997/1999-2010 were lower than those of $\mathrm{Hg}$. At Ainaži the levels of Cd differed by 3.3 times, at Saulkrasti by 1.6 times and at Mērsrags by 1.8 times. The differences in Cd levels at Ainaži, Saulkrasti and Mērsrags stations fluctuated by 1.2 to 2.3 times.

In 2007, the level of $\mathrm{Pb}$ in F. vesiculosus at all the three stations was 30-47.5 times higher than that in 2003 and 2005. Considerable differences in $\mathrm{Pb}$ levels between the three stations were observed in the years 1999, 2001, and 2003. Among the six metals studied, $\mathrm{Pb}$ had the highest variability in concentration (ANOVA test, Table 3). 
Table 1

TEMPERATURE, pH, SALINITY, SECCI DEPTH, DISSOLVED INORGANIC NITROGEN (DIN), DISSOLVED INORGANIC PHOSPHORUS (DIP) AND BIOMASS OF F. vesiculosus ( $\mathrm{g} / \mathrm{m}^{2}$ dry wt)

\begin{tabular}{|c|c|c|c|c|c|c|c|c|}
\hline Station & Year & $\mathrm{T},{ }^{\circ} \mathrm{C}$ & $\mathrm{pH}$ & $\mathrm{S}, \%$ & $\mathrm{DIN}, \mu \mathrm{M}$ & DIP, $\mu \mathrm{M}$ & Secci, m & $\begin{array}{c}\text { Biomass of } \\
\text { F. vesiculosus }\end{array}$ \\
\hline Ainaži & 1997 & 20.5 & 8.65 & 5.44 & 0.1 & 0.07 & - & - \\
\hline Saulkrasti & 1997 & 10.0 & 8.17 & 5.38 & 1.2 & 0.03 & - & - \\
\hline Ainaži & 1999 & 22.0 & 8.55 & 5.30 & 0.0 & 0.03 & 1.6 & - \\
\hline Saulkrasti & 1999 & 23.4 & 8.75 & 5.07 & 0.3 & 0.00 & 3.0 & - \\
\hline Mērsrags & 1999 & 24.5 & 8.87 & 4.96 & 1.2 & 0.04 & 2.0 & 223.43 \\
\hline Saulkrasti & 2001 & 19.8 & 8.40 & 4.56 & 5.7 & 0.29 & 2.0 & 73.23 \\
\hline Mērsrags & 2001 & 10.0 & 7.94 & 5.65 & 4.1 & 0.20 & 2.7 & 135.25 \\
\hline Ainaži & 2003 & 15.0 & 8.50 & 5.34 & 1.1 & 0.03 & 2.0 & - \\
\hline Saulkrasti & 2003 & 24.2 & 8.49 & 5.21 & 0.3 & 0.12 & 1.7 & 66.43 \\
\hline Mērsrags & 2003 & 19.0 & 8.30 & 5.45 & 0.5 & 0.16 & 3.0 & 159.35 \\
\hline Ainaži & 2005 & 18.0 & 8.53 & 5.11 & 1.0 & 0.05 & 1.9 & 23.16 \\
\hline Saulkrasti & 2005 & 18.8 & 8.58 & 4.54 & 0.7 & 0.15 & 1.4 & 83.54 \\
\hline Mērsrags & 2005 & 18.8 & 8.38 & 5.24 & 0.5 & 0.12 & 3.0 & 33.19 \\
\hline Ainaži & 2007 & 22.2 & 8.24 & 5.38 & 0.7 & 0.16 & 2.4 & 354.20 \\
\hline Saulkrasti & 2007 & 18.4 & 8.17 & 5.42 & 4.9 & 0.17 & 2.6 & 181.30 \\
\hline Mērsrags & 2007 & 22.0 & 8.21 & 5.26 & 1.6 & 0.13 & 3.0 & 425.65 \\
\hline Ainaži & 2009 & 19.1 & 8.38 & 5.40 & 0.7 & 0.25 & 2.2 & 88.61 \\
\hline Saulkrasti & 2009 & 18.0 & 8.91 & 5.16 & 3.4 & 0.28 & 1.1 & 46.64 \\
\hline Mērsrags & 2009 & 22.3 & 8.28 & 5.12 & 3.0 & 0.16 & 1.7 & 115.35 \\
\hline Mērsrags & 2010 & 20.0 & 8.66 & 4.83 & 0.7 & 0.08 & 3.0 & 261.88 \\
\hline Ainaži & 2010 & 20.4 & 8.52 & 4.84 & 4.0 & 0.09 & 2.1 & 254.83 \\
\hline Saulkrasti & 2010 & 17.8 & 8.53 & 5.21 & 3.1 & 0.04 & 2.0 & 52.20 \\
\hline
\end{tabular}

Table 2

CONCENTRATION OF METALS IN BROWN ALGAE $F$. vesiculosus OF THE GULF OF RĪGA (AUGUST/SEPTEMBER) (g/m² dry wt means/SD))

\begin{tabular}{|c|c|c|c|c|c|c|c|}
\hline$\underline{\text { Station }}$ & Year & $\mathrm{Hg}$ & $\mathrm{Cd}$ & $\mathrm{Pb}$ & $\mathrm{Cu}$ & $\mathrm{Ni}$ & $\mathrm{Zn}$ \\
\hline Ainaži & 1997 & $0.028 / 0.001$ & $1.36 / 0.13$ & 0.27 & $2.76 / 0.2$ & $6.34 / 0.38$ & $23.0 / 3.28$ \\
\hline Ainaži & 1999 & $0.019 / 0.001$ & 0.81 & 0.11 & 3.04 & 7.42 & 8.14 \\
\hline Ainaži & 2003 & $0.028 / 0.005$ & $3.63 / 0.04$ & 0.09 & $1.99 / 0.25$ & $11.0 / 0.6$ & 27.3/1.19 \\
\hline Ainaži & 2005 & 0.012 & $1.31 / 0.04$ & 0.06 & 1.6/0.01 & 3.4 & 22.22 \\
\hline Ainaži & 2007 & $0.014 / 0$ & $2.24 / 0.04$ & $2.7 / 0.11$ & $1.93 / 0.08$ & $8.62 / 0.33$ & $20.7 / 0.81$ \\
\hline Ainaži & 2009 & $0.035 / 0.001$ & $2.66 / 0.035$ & $0.75 / 0.07$ & $2.82 / 0.07$ & $12.33 / 0.07$ & $33.3 / 1.01$ \\
\hline Ainaži & 2010 & $0.027 / 0$ & $2.01 / 0.03$ & $0.33 / 0$ & $1.56 / 0.11$ & $10.34 / 0.15$ & $26.3 / 0.35$ \\
\hline Saulkrasti & 1999 & $0.024 / 0.001$ & 1.31 & 0.27 & 5,66 & 7.42 & 34.3 \\
\hline Saulkrasti & 2001 & $0.025 / 0.008$ & $0.98 / 0.03$ & 0.1 & $2.88 / 0.06$ & $5.11 / 0.3$ & $27.5 / 1.77$ \\
\hline Saulkrasti & 2003 & $0.037 / 0.005$ & $1.52 / 0.04$ & 0.08 & $2.57 / 0.07$ & $10.4 / 0$ & $34.8 / 0.07$ \\
\hline Saulkrasti & 2005 & 0.014 & $1.12 / 0.08$ & 0.06 & 2.48 & 6.56 & $29.9 / 2.25$ \\
\hline Saulkrasti & 2007 & $0.012 / 0$ & $1.61 / 0.04$ & $2.85 / 0.10$ & $2.11 / 0.06$ & $8.3 / 0.29$ & $29.4 / 0.87$ \\
\hline Saulkrasti & 2009 & $0.020 / 0.001$ & $1.15 / 0.01$ & $0.83 / 0.07$ & $2.42 / 0.23$ & $6.61 / 1.25$ & $31 / 0.66$ \\
\hline Saulkrasti & 2010 & $0.071 / 0.001$ & $1.5 / 0$ & $0.35 / 0.03$ & $2.42 / 0.07$ & $8.84 / 0.82$ & $38.0 / 0.82$ \\
\hline Mērsrags & 1999 & $0.01 / 0$ & $1.52 / 0.05$ & 0.2 & $2.87 / 0.59$ & $8.57 / 0.59$ & $26.8 / 0.84$ \\
\hline Mērsrags & 2001 & $0.025 / 0.008$ & $1.72 / 0.06$ & 0.25 & $3.41 / 0.31$ & $10.72 / 0.57$ & $41.9 / 2.36$ \\
\hline Mērsrags & 2003 & $0.019 / 0.004$ & $1.87 / 0.05$ & 0.05 & $2.35 / 0.06$ & $11.1 / 0.2$ & $33.7 / 0.56$ \\
\hline Mērsrags & 2005 & 0.013 & $1.1 / 0.1$ & $0.08 / 0.01$ & 2.6 & 6.29 & $23.8 / 1.39$ \\
\hline Mērsrags & 2007 & 0.012 & $1.94 / 0.04$ & $2.77 / 0.04$ & $1.9 / 0.04$ & $8.21 / 0.21$ & $29.2 / 0.67$ \\
\hline Mērsrags & 2009 & $0.012 / 0$ & $1.68 / 0.02$ & $0.70 / 0.07$ & $2.63 / 0.04$ & $8.83 / 0.19$ & $29.3 / 0.99$ \\
\hline Mērsrags & 2010 & $0.046 / 0$ & $1.67 / 0.05$ & $0.27 / 0.03$ & $2.43 / 0.46$ & $9.32 / 0.46$ & $24.6 / 1.39$ \\
\hline
\end{tabular}


Table 3

VALUES OF TWO-FACTOR ANALYSIS OF VARIANCE WITHOUT REPLICATION FOR BROWN ALGAE F. vesiculosus (ns, not significant)

\begin{tabular}{l|ccc|c|ccc}
\hline \multicolumn{5}{c|}{ Years } & \multicolumn{3}{c}{ Stations } \\
\hline & df & $\mathrm{F}$ & $P$ level & df & $\mathrm{F}$ & $P$ level \\
\hline $\mathrm{Hg}$ & 5 & 4.445 & 0.02 & 2 & 1.176 & $\mathrm{~ns}$ \\
$\mathrm{Cd}$ & 5 & 0.395 & $\mathrm{~ns}$ & 2 & 3.430 & $\mathrm{~ns}$ \\
$\mathrm{~Pb}$ & 5 & 1587.300 & 0.00 & 2 & 3.979 & 0.05 \\
$\mathrm{Cu}$ & 5 & 2.931 & $\mathrm{~ns}$ & 2 & 2.002 & $\mathrm{~ns}$ \\
$\mathrm{Ni}$ & 5 & 4.894 & 0.02 & 2 & 2.032 & $\mathrm{~ns}$ \\
$\mathrm{Zn}$ & 5 & 0.611 & $\mathrm{~ns}$ & 2 & 3.412 & $\mathrm{~ns}$
\end{tabular}

Differences in $\mathrm{Cu}$ concentration in $F$. vesiculosus between years were lower than those of other metals: at Ainaži by 1.9 times, at Saulkrasti by 2.9 times and at Mērsrags by 1.8 times. The differences in $\mathrm{Cu}$ level in $F$. vesiculosus at stations Ainaži, Saulkrasti and Mērsrags were even lower by 1.1-2.1 times.

Considerable yearly differences in $\mathrm{Ni}$ level were observed (ANOVA test, Table 3): the differences in Ni concentration in $F$. vesiculosus (at Ainaži by twice, at Saulkrasti by twice and at Mērsrags by 1.8 times) were similar to those of $\mathrm{Cu}$. Differences in Ni level in F. vesiculosus between the stations (1.1-2.1) were also similar to those of $\mathrm{Cu}$ levels. In 2005 and 2007, there were no significant differences in $\mathrm{Ni}$ levels between the stations.

Large yearly differences in $\mathrm{Zn}$ levels were observed only at Ainaži (by 4.1 times), compared to those at Saulkrasti and Mērsrags (1.4 and 1.8 times, respectively).

Significant differences in $\mathrm{Zn}$ levels (4.2 times) between the three stations occurred only in 1999. In the other years the levels of $\mathrm{Zn}$ in $F$. vesiculosus showed small differences between the stations Ainaži, Saulkrasti and Mērsrags (1. 1-1.5 times).

Significant differences of $\mathrm{Hg}, \mathrm{Pb}, \mathrm{Ni}$ concentrations between years were observed in the macroalgae $F$. vesiculosus (ANOVA test, Table 3). There were no significant differences of $\mathrm{Hg}, \mathrm{Cd}, \mathrm{Cu}, \mathrm{Ni}$, and $\mathrm{Zn}$ concentrations between the sampling stations, only tendencies. The highest metal levels in $F$. vesiculosus at the three stations occurred most often at Saulkrasti $-43 \%$, then at Ainaži $-31 \%$, followed by Mērsrags - $26 \%$.

\section{DISCUSSION}

In 1978, the following levels of metals were found in the brown algae $F$. vesiculosus at Mērsrags and Ragaciems (Сейсума и др., 1984): Cd 4.21-4.25, Сu 5.55-6.65, Pb $11.20-14.96$, and $\mathrm{Zn} 110.55-193.55 \mathrm{mg} / \mathrm{kg}$ of dry weight. About ten years later Estonian scientists ( Kukk et al., 1988) observed much lower concentrations of metals in $F$. vesiculosus at Ragaciems (Cd 2.40, $\mathrm{Cu} 5.42, \mathrm{~Pb} 0.40 \mathrm{mg} / \mathrm{kg}$ of dry weight).
In 1999, upon resuming systematic studies of metals in the brown algae $F$. vesiculosus, we also observed a decline of metal levels (Table 2), in comparison with those in previous decades. In 1999, the highest levels of $\mathrm{Hg}, \mathrm{Pb}, \mathrm{Cu}$, and $\mathrm{Zn}$ in F. vesiculosus were found at Saulkrasti and the lowest at Mērsrags. At Saulkrasti the concentrations of these metals in water and sediment were also higher than those at Mērsrags (Seisuma and Kulikova, 2000). In 1999, there was a much higher difference among the levels of $\mathrm{Hg}, \mathrm{Cd}, \mathrm{Pb}$, $\mathrm{Cu}, \mathrm{Ni}$ and $\mathrm{Zn}$ in brown algae of both stations than in 2005, when the metal concentrations in water and sediment along the whole coast of the Gulf of Riga were similar. For example, in 1999, $\mathrm{Cu}$ concentration in waters at Mērsrags and Saulkrasti ranged from 3.6-6.6 $\mu \mathrm{g} / \mathrm{l}$. In 2005, the range of $\mathrm{Cu}$ levels in water was only 3.7 to $3.9 \mu \mathrm{g} / \mathrm{l}$ at both stations. In 2001, the highest levels of $\mathrm{Zn}$ in $F$. vesiculosus and water were found at Mērsrags. Metals needed for development of aquatic plants are absorbed from water and sediments.

The high levels of $\mathrm{Hg}, \mathrm{Cd}, \mathrm{Cu}, \mathrm{Ni}$ and $\mathrm{Zn}$ in F. vesiculosus at Ainaži in 2009 may indicate impact of nearby urban areas (the ports Salacgrīva and Kuiviži) and of the breakwater of the old Ainaži port and three damping sites nearby.

To identify relationships between $\mathrm{Hg}, \mathrm{Cd}, \mathrm{Pb}, \mathrm{Cu}, \mathrm{Ni}$, and $\mathrm{Zn}$ concentrations in $F$. vesiculosus at sampling stations, principal component analysis (PCA) using a correlation matrix was performed. The Varimax method was used to rotate initial factors and derive components that represented groups of related variables and samples. Ainaži 2009 and Ainaži 2010, which had the highest concentrations of these variables, had the highest positive loadings (1.937 and 1.183) on PCA component 1. On the opposite side of the component, Mērsrags 2005 and Saulkrasti 2005 had the highest negative scores $(-1.33$ and -1.22$)$ (Fig. 2). There was a positive correlation $(P<0.01)$ between $\mathrm{Cd}$ and $\mathrm{Ni}$ in F. vesiculosus.

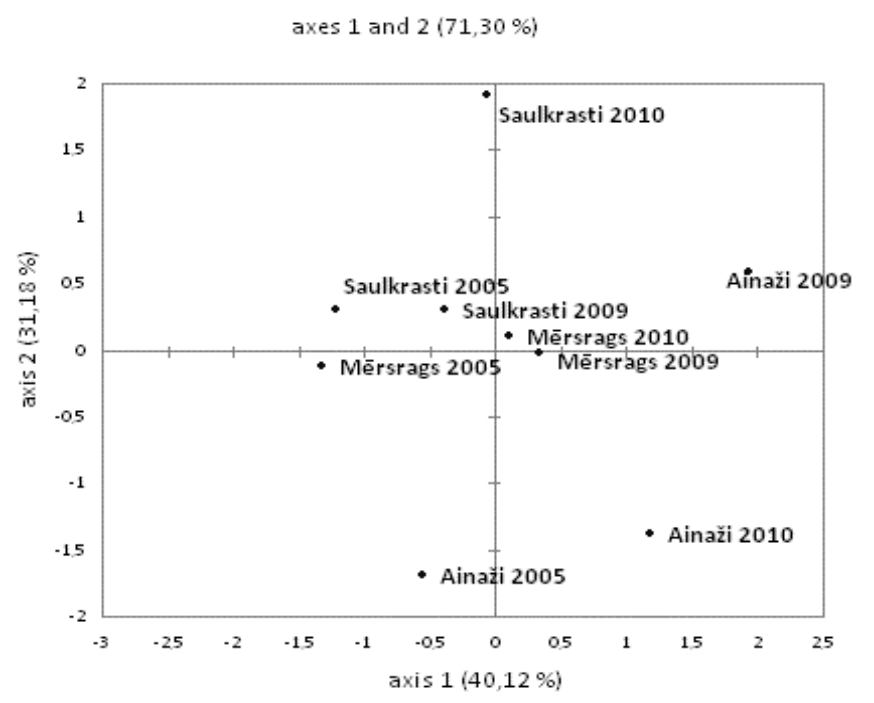

Fig. 2. Principal Components Analysis axis scores for Ainaži, Saulkrasti and Mērsrags stations. Data for F. vesiculosus (August/September 2005, 2009, 2010) 
Table 4

MEAN CONCENTRATION FACTORS $\left(* 10^{3}\right)$ EXPRESSED ON A DRY AND WET WEIGHT (wt) BASIS FOR CU, NI AND ZN IN BROWN ALGAE $F$. vesiculosus IN DIFFERENT STATIONS

\begin{tabular}{l|ccc|c|c|cc}
\hline \multirow{2}{*}{ Station, year } & \multicolumn{2}{c|}{$\mathrm{Cu}$} & \multicolumn{2}{c|}{$\mathrm{Ni}$} & \multicolumn{2}{c}{ Zn } \\
\cline { 2 - 7 } & dry wt & wet wt & dry wt & wet wt & dry wt & wet wt \\
\hline Ainaži, 1999 & 0.74 & 0.20 & 2.58 & 0.69 & 3.43 & 0.92 \\
Saulkrasti, 1999 & 1.71 & 0.45 & 6.51 & 1.70 & 12.25 & 3.19 \\
Mērsrags, 1999 & 0.80 & 0.20 & 6.64 & 1.64 & 8.99 & 2.22 \\
Ainaži, 2009 & 3.86 & 1.11 & 15.40 & 4.42 & 9.51 & 2.73 \\
Saulkrasti, 2009 & 2.95 & 0.37 & 5.51 & 0.69 & 17.22 & 2.16 \\
Mērsrags, 2009 & 2.90 & 0.78 & 8.03 & 2.16 & 7.51 & 2.03
\end{tabular}

H. R. Voigt (2007) determined mean concentrations of $\mathrm{Cu}$, $\mathrm{Zn}, \mathrm{Cd}$ in $F$. vesiculosus at Tvaerminne, Finnish western Gulf of Finland (1995-2005) to be: $\mathrm{Cu}-4, \mathrm{Zn}-52, \mathrm{Cd}-$ $0.65 \mathrm{mg} / \mathrm{kg}$ dry wt. These concentrations of $\mathrm{Cu}, \mathrm{Zn}$, and $\mathrm{Cd}$ are close to those observed in our investigations (Table 2).

Concentration factors ( $\mathrm{CFs}$ ) were determined to assess the bioaccumulation ability of the brown algae $F$. vesiculosus. This was done by comparing the concentrations in algae and water collected at the same sites and times. CF is the ratio of metal concentration in the plant $(\mu \mathrm{g} / \mathrm{kg}$ dry or wet weight) to the concentration of metal in seawater $(\mu \mathrm{g} / \mathrm{l})$. $\mathrm{CFs}$ may be influenced by the passage of a contaminant through the trophic chain. Concentration factors for $\mathrm{Cu}, \mathrm{Ni}$, and $\mathrm{Zn}$ were observed to be $10^{3}$ (Table 4). Brown algae $F$. vesiculosus has the ability to accumulate metals to a level thousand times more than in marine water. In this respect, it is important to consider that macroalgae is also a food source for invertebrate and fish. Similar observations have been made for other macroalgae (Szefer, 1991; Akcali and Kucuksezgin, 2011).

Based on our results and data from literature (Bryan and Hummerstone, 1973, Sanchez-Rodriguez et al., 2001), we can conclude that the capacity of macroalgae to accumulate metals depends on a variety of factors, such as location, temperature, salinity, light, $\mathrm{pH}$, nitrogen availability, metabolic processes and the affinity of the plant for each metal. However, the two main factors affecting element levels in aquatic plants most likely are the bioavailability of metals in the surrounding water and the uptake capacity of the algae.

\section{ACKNOWLEDGEMENT}

A Latvian Council of Science grant "Functional biodiversity of the communities of the Gulf of Riga under anthropogenic impact", financially supported this study. The authors are very grateful to Nauris Petrovics for his excellent SCUBA diving for macrophyte sampling as well as for providing data of macrophyte distribution.

\section{REFERENCES}

Akcali, I., Kucuksezgin, F. (2011). A biomonitoring study: Heavy metals in macroalgae from eastern Aegean costal areas. Marine Pollut. Bull., 62(3), $637-645$.

Anonymous (1998). SAS/STAT ${ }^{B} /$ User's Guide. SAS Institute Inc., Cary, NC. 1028 pp.

Anonymous (2010). HELCOM. Hazardous substances in the Baltic Sea: An integrated thematic assessment of hazardous substances in the Baltic Sea. Balt. Sea Environ. Proc. 120B. 116 pp.

Arhipova, I., Bāliņa, S. (2003). Statistika ekonomikā. Risinājumi ar SPSS un Microsoft Excel. Mācību līdzeklis. Rīga: Datorzinību centrs. 352 lpp.

Barnett, B.E., Ashcroft, C.R. (1985). Heavy metals in Fucus vesiculosus in the Humber Estuary. Environ. Pollut. Series B. Chemical and Physical, 9(3), 193-213.

Barreiro, R., Picado, L., Real, C. (2002). Biomonitoring heavy metals in estuaries: A field comparison of two brown algae species inhabiting upper estuarine reaches. Environ. Monitor. Assess., 75, 121-134.

Boikova, E., Botva U., Līcīte V., Jermakovs V., Kuḷikova I., Seisuma Z., Petrovics N. (2003). The littoral biotopes of the Gulf of Riga and their role in sustainable coastal zone development. Proceedings of the International Conference "Eco Balt '2003”, Rīga, May 15-16 (Vol. 2, pp. 72-74). Rīga.

Bryan, G.W., Hummerstone, L.G. (1973). Brown seaweed as indicator of heavy metals in estuaries in southwest England. J. Mar. Biol. Assoc. UK, 53, 705-720.

Bryan, G. W. (1983) Brown seaweed, Fucus vesiculosus, and the gastropod Littorina littoralis, as indicators of trace metal availability in estuaries. Sci. Total Environ, 28, 91-104.

Cairrao, E., Pereira, M.J., Pastorinho, M. R., Morgado, F., Soares, A. M. V. M., Guilhermino L. (2007). Fucus spp. As a Mercury Contamination Bioindicator in Costal Areas (Northwestern Portugal). Bull. Environ. Contam. Toxicol., 79, 388-395.

Forsberg, A., Soderlund, S., Frank, A., Peterson, L. R., Pedersen, M. (1988). Studies on metal content in the brown seaweed, Fucus vesiculosus, from the Archipelago of Stockholm. Environmental Pollution, 49(4), 245-263.

Kukk, H., Jankovski, H., Volož, J. (1988). Accumulation of heavy metals in the Baltic Sea macrophytes. In: Proceedings of $16^{\text {th }}$ Conference of the Baltic Oceanographers. September. Vol. 2. 623-630.

Martin, G. (1999). Distribution of phytobenthos biomass in the Gulf of Riga (1984-1991). Hydrobiologia, 393, p. 181-190.

Morrison, L., Baumann, H. A., Stengel, D. B. (2008). An assessment of metal contamination along the Irish coast using the seaweed Ascophyllum nodosum (Fucales, Phaeophyceae). Environmental Pollution, 152, 293-303.

O'Leary, C., Breen, J. (1998). Seasonal variation of heavy metals in Mytilus edulis, Fucus vesiculosus and sediment from the Shannon Estuary. Biology and Environment: Proc. Royal Irish Academy, 98B, 3, 153-169.

Phillips, D. J. H. (1977). The use of biological indicator organisms to monitor trace metal pollution in marine and estuarine environment: A review. Environ. Pollut., 13, 281-317.

Seisuma, Z., Kulikova, I. (2000). Metals in sediments and water of the coastal zone of the Gulf of Riga, The Baltic Sea. Proc. Latvian Acad. Sci., Section B, 54, 5/6 (610/611), 148-154.

Seisuma, Z., Kulikova, I. (2006). Distribution of metals in water and sediment of the coastal zone of the Gulf of Riga. International conference Eco-Balt'2006, May 11-12, 2006, Riga, Latvia, pp.127-128.

Szefer, P. (1991). Interphase and trophic relationships of metals in a southern Baltic ecosystem. Sci. Tot. Environ., 101, 201-215.

Voigt, H.-R. (2007). Heavy metals in sediment and biota in the coastal area of the Gulf of Finland, Baltic Sea. $42^{\text {nd }}$ European Marine Biology Symposium (EMBS 42), 27-31.8. Kiel, Germany - Book of Abstracts, p. 216.

Сейсума 3., Куликова, И. Вадзис Д. , Легздиня М. (1984). Тяжелье металлы в гидробионтах Рижского залива. Серия "Биология Балтийского моря'’. Вып. V, Рига: Зинатне, 179 с. 
METĀLU KONCENTRĀCIJU ILGTERMIN̦A PĒTĪJUMI BALTIJAS JŪRAS RĪGAS LİČA BRŪNAḶĜ̣̄ Fucus vesiculosus

Pētījumi veikti Rīgas līča piekrastes zonā trīs stacijās (Ainaži, Saulkrasti, Mērsrags) no 1997. gada līdz 2010. gadam. Pētījumu mērḳis bija noteikt metālu $(\mathrm{Hg}, \mathrm{Cd}, \mathrm{Pb}, \mathrm{Cu}, \mathrm{Ni}, \mathrm{Zn})$ koncentrāciju līmeni Rīgas līča dominējošā makroaḷg̣è $F$. vesiculosus dažāaās stacijās un gados. Brūnaḷ̆ge tika ievākta augustā/septembrī $3 \mathrm{~m}$ dziḷumā ar ūdenslīdēja palīdzību. Metālu (Cd, Pb, Cu, Ni, Zn) koncentrācijas noteiktas ar atomabsorbcijas spectrometru VARIAN Spectra AA 880, Hg — ar FIMS (Perkin Elmer).

Metālu koncentrācijas $F$. vesiculosus variē pa gadiem un stacijām, bet statistiski būtiskas atškirības ir tikai $\mathrm{Hg}$, Pb un Ni koncentrācijām brūnaḷgè pa gadiem. Dažos gados metālu koncentrācijas $F$. vesiculosus ir vienādas visās trijās stacijās. Brūnaḷ̆ge $F$. vesiculosus var akumulēt metālus tūkstoš reižu lielākās koncentrācijās, nekā tās ir jūras ūdenī. 